\title{
Penegakan Hukum Terhadap Pengangkutan Bahan Bakar Minyak Subsidi Tanpa Ijin Usaha Pengangkutan
}

\author{
H. Muhammad Asri \\ Fakultas Hukum, Universitas Muhammadiyah Sorong \\ Email : Polisiasri@gmail.com
}

\begin{abstract}
Abstrak
Penelitian ini dilaksanakan di Kantor Pengadilan Kota Sorong dengan mengambil sebanyak 2 orang Hakim, 3 orang saksi dan terdakwa sebagai sampel pengamatan yang diberikan wawancarai. Teknik pengumpulan data yaitu observasi dan wawancara terstruktur dengan responden, juga diadakan wawancara bebas dengan para pegawai tertentu serta menelaah naskah-naskah asli (dokumen). Analisis data dilakukan dengan menggunakan analisis deskripsi kualitatif.

Berdasarkan hasil penelitian dan pembahasan maka dapat disimpulkan bahwa Pada perkara Nomor 105/Pid.B/2017/PN.Son Majelis Hakim memutuskan bahwa terdakwa telah terbukti secara sah dan meyakinkan bersalah telah melakukan tindak pidana "Menyalahgunakan Pengangkutan Dan Niaga Bahan Bakar Minyak Yang Disubsidi Pemerintah. Terdakwa MUNAWAR KHALIL Alias ALE telah terbukti melanggar Pasal 55 UU RI No. 22 Tahun 2001 tentang Minyak dan Gas Bumi. Namun, menurut penulis hakim dan Jaksa Penuntut Umum dalam menerapkan hukum pidana lebih tepat jika memutus terdakwa melanggar Pasal 53 Undang-undang Nomor 22 Tahun 2001 tentang Minyak dan Gas Bumi. Dalam memutus suatu perkara, Majelis Hakim Pengadilan Negeri Sorong lalai dalam menerapkan hukum dengan tidak mempertimbangkan secara matang dakwaan dari Jaksa Penuntut Umum. Majelis Hakim menjatuhkan vonis kepada terdakwa Pasal 55 Undangundang Nomor 22 Tahun 2001 bukan Pasal 53 Undang- undang Nomor 22 Tahun 2001, sehingga putusan hakim dapat dikatakan keliru.
\end{abstract}

Kata Kunci : Penegakan Hukum, Bahan Bakar Minyak, Subsidi, Ijin Usaha

\section{PENDAHULUAN}

Seiring dengan meningkatnya kebutuhan manusia di bidang produksi minyak, sejak saat itu juga banyak terjadi tindak pidana terhadap penjualan dan pengangkutan bahan bakar minyak (selanjudnya disingkat BBM) yang disubsidi oleh pemerintah terhadap perlindugan di bidang produksi khususnya terhadap produksi BBM. dan tak tanggung-tanggung pelakunya warga indonesia, hal ini tentunya berpengaruh besar dan sangat sensitif dampaknya terhadap kelansungan hidup orang banyak, sebab kerugian yang di timbulkan dalam perbuatan hukum ini yaitu terbatasnya pasokan BBM ke masyarakat.

Tindak pidana Pengangkutan bahan bakar minyak tampa ijin usaha hal ini di karenakan harga BBM yang bersubsidi jauh lebih rendah harganya jika di bandingkan dengan harga BBM yang tidak disubsidi oleh pemerintah, tindak pidana seperti ini biasa dilakukan oleh orang yang 
tertentu Setelah melakukan pesngangkutan bahan bakar minyak kemudian menjualnya ke masingmasing tempat dengan harga yang relatif tinggi.

Mungkin indonesia satu-satunya Negara anggota OPEC yang menderita apabilah terjadinya kenaikan harga minyak internasional. Masalah ini berlansung dari tahun ketahun seolaholah kita tidak berdaya dan tentunya secara mudah kita dapat katakan bahwa salah satu penyebabny adalah kualitas manejemen Migas nasional yang kurang memandai.

Undang-undan Nomor 22 tahun 2001 tentang minyak dan gas bumi telah disahkan dan di undangkan pada tanggal 23 November 2001 merupakan tonggak sejarah dalam memberikan landasan hukum bagi langkah-langka pembaruhan dan penataan kembali kegiatan usaha Minyak dan Gas Bumi yang terdiri dari usaha hilir yang terdiri dari pengololahan, pengangkutan dan penyimpanan, dan niaga tersebut terdapat kegiatan penyimpanan pendistribusian BBM dan pengangkutan gas bumi melalui pipa, agar penyediaan dan pendistribusian BBM dapat di laksanakan. Sebagaimana diatur dan diancam pidana pasal 55 Undang-Undang RI Nomor 22 Tahun 2001 tentang Minyak dan Gas Bumi jo. Pasal 55 Ayat (1) Ke-1 KUHP.

Maka tindakan pidana yang di lakukan oleh pelaku tersebut yang di lakukan degan mengunakan mobil, yang di lakukan dengan tujuan untuk memperoleh keuntungan yang besar maka dilakukan tindakan pengangkutan bahan bakar minyak tamp ijin usaha pengangkutan.

Dari uraian di atas maka tidak dapat dipungkiri bahwa terjadi tindak pidana pengangkutan bahan bakar minyak tampa ijin usaha pengangkutan kususnya yang terjadi di kota sorong, maka itu peranan pemerintah merupakan salah satu syarat penting dalam pencegahan terjadinya pengangkutan bahang bakar minyak tampa ijin usaha pengangkutan terhadap pendistribusian BBM bersubsidi di Kota Sorong.

Tidak meratanya pendistribusian hasil komonitas bumi di daerah dan banyanyaknya daerah kepulauan yang mata pencarian sebagai nelayan, membutuhkan hasil bumi terkhusus di daerah kepulauan, salah satu dari olahan minyak dan gas bumi yaitu bahan bakar minyak berupa bensin dan solar.

BPH migas adalah badan yang di bentuk berdasarkan pasal 8 ayat (4) dan pasal 46 undangundang nomor 22 tahun 2001 tentang Minyak dan Gas Bumi. BPH migas diatur dalam peraturan pemerintah Nomor 67 tahun 2002 jo keputusan Presiden Nomor 86 Tahun 2002 tentang badang pengatur penyediaan pendistribusian BBM Migas pasal 46 undang-undang Nomor 22 Tahun 2001 Tentang Minyak dan Gas Bumi pengawasan terhadap pelaksanaan penyediaan dan 
pendistribusikan bahan Bakar Minyak dan Pengangkutan Gas bumi. Pasal 53 huruf c UndangUndang Nomor 22 Tahun 2001 Tentang Minyak dan Gas Bumi menyatakan bahwa setiap orang yang melakukan penyimpanan sebagaimana dimaksud dalam pasal 23 tampa Ijin Usaha penyimpanan dipidana; (1) Bagamana Tinjauan Hukum Tindak Pidana Terhadap Pengangkutan Bahan Bakar Minyak Subsidi Tanpa Ijin Usaha Pengangkutan (Studi Kasus No : 105/pid/b/2017/pn son); (2) Kendala-kendala apa yang di hadapi dalam Penegakan hukum tindak pidana terhadap Pengangkutan Bahan Bakar Minyak Subsidi Tanpa Ijin Usaha Pengangkutan?

\section{PEMBAHASAN}

\section{Pengertian Penegakan Hukum}

Pengertian penegakan hukum dapat di rumuskan sebagai usaha melaksanakan hukum sebagaimana mestinya, mengawasi pelaksanannya agar tidak terjadi pelanggaran dan jika terjadi pelanggaran memulihkan hukum yang dilanggar itu supaya dapat ditegakan kembali. Hukum mengatur masyarakat secara patut dan bermanfaat dengan menetapkan apa yang harus dilakukan ataupun yang dibolehkan dan sebaliknya. Bahkan yang diperhatikan dan digarap oleh hukum adalah justru perbuatan yang disebut terakhir ini, baik perbuatan melawan hukum yang benarbenar terjadi maupun perbuatan hukum yang mungkin akan terjadi. Perhatian dan penggarapan perbuatan itulah yang merupakan penegakan hukum.

Penegakan hukum merupakan suatu proses dilakukannya upaya untuk tegaknya atau berfungsinya norma-norma hukum secara nyata sebagai pedoman perilaku dalam lalu lintas dan hubungan-hubungan hukum dalam kehidupan bermasyarakat dalam bernegara. Ditinjau dari sudut subjeknya, penegakan hukum itu dapat dilakukan oleh subjek yang luas dan dapat pula diartikan sebagai upaya penegakan hukum oleh subjek hukum dalam arti yang terbatas atau sempit.

Dalam arti luas, proses penegakan hukum itu melibatkan semua subjek hukum dalam setiap hubungan hukum. Siapa saja yang menjalankan aturan normative atau melakukan sesuatu atau tidak melakukan sesuatu dengan mendasarkan diri pada norma aturan hukum yang berlaku, berarti dia menjalankan atau menegakkan aturan hukum.

Dalam arti sempit, dari segi subjeknya itu, penegakan hukum itu hanya diartikan sebagai upaya aparatur penegakan hukum tertentu untuk menjamin dan memastikan bahwa suatu aturan hukum berjalan sebagaimana seharusnya. Dalam memastikan tegaknya hukum itu, apabila diperlukan, aparetur penegak hukum itu diperkenenkan untuk menggunakan daya paksa. 
Pengertian penegakan hukum itu dapat pula ditinjau dari sudut objeknya, yaitu dari segi hukumnya. Dalam hal ini pengertiannya juga mencakup makna yang luas dan sempit. Dalam arti luas, penegakan hukum itu mencakup pula nilai-nilai keadilan yang terkandung didalamnya bunyi aturan formal maupun nilai-nilai keadilan yang hidup dalam masyarakat. Tetapi dalam arti sempit, penegakan hukum itu hanya menyangkut penegakan peraturan yang formal dan tertulis saja. Karena itu, penerjemahan perkataan "law enforcement" ke dalam bahasa Indonesia dalam menggunakan perkataan "penegakan hukum" dalam arti luas dan dapat pula digunakan istilah "penegakan peraturan" dalam arti sempit.

Pembeda antara formalitas aturan hukum yang tertulis dengan cakupan nilai keadilan yang dikandungnya ini bahkan juga timbul dalam bahasa Inggris sendiri dengan dikembangkannya istilah "the rule of law" versus "the rule of just law" atau dalam istilah "the rule of law and not of man" versus istilah "the rule of law" yang berarti "the rule of man by law" dalam istilah "the rule of law" terkandung makna pemerintahan oleh hukum, tetapi bukan dalam arti yang formal, melainkan mencakup pula nilai-nilai keadilan yang terkandung didalamnya. Karena itu, digunakan istilah "the rule of just law".

Dalam istilah the rule of law and not of man" dimaksudkan untuk menegaskan bahwa pada hakikatnya pemerintahan suatu negara hukum modern itu dilakukan oleh hukum, bukan oleh orang. Istilah sebaliknya adalah "the rule by law" yang dimaksudkan sebagai pemerintah oleh orang yang menggunakan hukum sekedar sebagai alat kekuasaan belaka.

Dengan uraian di atas jelaslah kiranya bahwa yang dimaksud dengan penegakan hukum itu merupakan upaya yang dilakukan utuk menjadikan hukum, baik dalam arti formil yang sempit maupun dalam arti materil yang luas, sebagai pedoman perilaku dalam setiap perbuatan hukum, baik oleh para subjek hukum yang bersangkutan maupun oleh aparatur penegakan hukum yang resmi diberi tugas dan kewenangan oleh undang-undang untuk menjamin berfungsinya normanorma hukum yang berlaku dalam kehidupan bermasyarakat dan bernegara.

\section{Penegakan Hukum Objektif}

Seperti disebut dimuka, secara objektif, norma hukum yang hendak ditegakkan mencakup pengertian hukum formal dan hukum materil. Hukum formal hanya bersangkutan dengan peraturan perundang-undangan yang tertulis, sedangkan hukum materil mencakup pula pengertian nilai- nilai keadilan yang hidup dalam masyarakat. 
Dalam bahasa yang tersendiri, kadang-kadang orang membedakan antara pengertian penegakan hukum dan penegakan keadilan. Penegakan hukum dapat dikaitkan dengan pengertian "law enforcement" dalam arti sempit, sedangkan penegakan hukum dalam arti luas, dalam arti hukum materil, diistilahkan dengan penegakan keadilan. Dalam bahasa Inggris juga terkadang dibedakan antara konsepsi "court of law" dalam arti pengadilan hukum dan "court of justice" atau pengadilan keadilan. Bahkan, dengan semangat yang sama pula, Mahkama Agung di Amerika Serikat disebut dengan istilah "supreme court of justice". Istilah-istilah itu dimaksudkan untuk menegaskan bahwa hukum yang harus ditegakkan itu pada intinya bukanlah norma aturan itu sendiri, melainkan nilai-nilai keadilan yang terkandung di dalamnya. Masalah penegakan hukum, baik secara "in abstracto" maupun secara "in concreto" merupakan masalah aktual yang akhirakhir ini mendapat sorotan tajam dari masyarakat.

\section{Faktor-Faktor Yang Mempengaruhi Penegakan Hukum}

Semenjak dilahirkan didunia, maka manusia telah mempunyai hasrat untuk hidup secara teratur. Hasrat untuk hidup secara teratur tersebut dipunyainya sejak lahir dan selalu berkembang di dalam pergaulan hidupnya. Namun apa yang dianggap teratur oleh seseorang belum dianggap teratur juga oleh pihak-pihak lainnya. Oleh karena itu, maka manusia sebagai mahkluk yang senantiasa hidup bersama dengan sesamanya, memerlukan perangkat patokan agar tidak terjadi pertentangan kepentingan sebagai akibat dari pendapat yang berbeda-beda mengenai keteraturan tersebut. Patokan-patokan tersebut tidak lain merupakan pedoman untuk berprilaku secara pantas yang sebenarnya merupakan suatu pandangan menilai yang sekaligus merupakan suatu harapan.

Patokan-patokan untuk berprilaku pantas tersebut, kemudian dikenal dengan sebutan norma atau patokan-patokan untuk berprilaku pantas tersebut, kemudian dikenal dengan sebutan norma atau kaidah. Norma atau kaidah tersebut mungkin timbul dari pandangan-pandangan mengenai apa yang dianggap baik atau dianggap buruk, yang lazimnya disebut nilai. Kadang kala norma atau kaidah tersebut timbul dari pola perilaku manusia (yang ajeg), sebagai suatu abstraksi dari prilaku berulang-ulang yang nyata.

Norma atau kaidah tersebut untuk selanjutnya mengatur diri pribadi manusia, khususnya menegenai bidang-bidang kepercayaan dan kesusilaan. Norma atau kaidah kepercayaan bertujuan agar manusia mempunyai kehidupan yang berima, sedangkan norma atau kaidah kesusilaan bertujuan agar manusia mempunyai hati nurani yang bersih. Di samping itu maka norma atau kaidah mengatur pula kehidupan antar pribadi manuisa, khususnya mengenai bidang-bidang 
kesopanan dan hukum. norma atau kaidah kesopanan bertujuan agar manusia mengalami kesenangan atau kenikmatan di dalam pergaulan hidup bersama dengan orang-orang lain. Norma atau kaidah hukum bertujuan agar tercapai kedamaian di dalam kehidupan bersama, di mana kedamaian berarti suatu keserasian antara keterikanatan dengan kebebasan. Itulah yang menjadi tujuan hukum, sihingga tugas hukum adalah tidak lain dari pada mencapai suatu keserasian antara kepastian hukum dengan kesebandingan hukum.

Istilah Tindak Pidana

Istilah tindak pidana berasal dari istilah yang dikenal dalam hukum pidana Belanda yaitu strafbaar feit. Walaupun istilah ini terdapat dalam WvS Belanda, dengan demikian juga WvS Hindia Belanda (KUHP), tetapi tidak ada penjelasan resmi tentang apa yang dimaksud dengan strafbaar feit itu.

Istilah-istilah yang pernah digunakan, baik dalam perundang- undangan yang ada maupun dalam berbagai literatur hukum sebagai terjemahan dari istilah strafbaar feit adalah sebagai berikut;

Tindak pidana, dapat dikatakan berupa istilah resmi dalam perundang- undanagan pidana kita. Hampir seluruh peraturan perundang-undangan menggunakan istilah tindak pidana; (a) Peristiwa pidana, digunakan oleh beberapa ahli hukum, misalnya Mr. R. Tresna dalam bukunya azas-azas hukum pidana, Mr. H.J. Van Schravendijk dalam bukun pelajaran tentang hukum pidana Indonesia; (b) Delik, yang sebenarnya berasal dari bahasa latin delictum juga digunakan untuk menggambarkan tentang apa yang dimaksud dengan strafbaar feit; (c) Pelanggaran pidana, dapat dijumpai dalam pokok-pokok hukum pidana yang ditulis oleh Mr. M.H. Tirtamidjaja; (d) Perbuatan yang boleh dihukum, istilah ini digunakan oleh Mr. Karni dalam buku beliau ringkasan tentang hukum pidana, begitu juga Mr. H.J. Van Schravendijk dalam bukunya pelajaran tentang hukum pidana Indonesia; (e) Perbuatan yang dapat dihukum, digunakan oleh pembentuk undangundang dalam Undang-Undang Nomor 12/Drt/1951 Tentang Senjata Api dan Bahan Peledak; (f) Perbuatan pidana, digunakan oleh Moeljadno dalam berbagai tulisan beliau, misalnya dalam buku azas-azas hukum pidana.

Strafbaar feit, terdiri dari tiga kata, yakni straf, baar, dan feit. Dari tujuh istilah yang digunakan sebagai terjemahan dari strafbaar feit itu, tenyata straf diterjemahkan dengan pidana dan hukum. Perkataan baar dapat diterjemahkan dengan dapat dan boleh. Sementara itu feit diterjemahkan dengan tindak, peristiwa, pelanggaran, dan perbuatan. 


\section{Pengertian Tindak Pidana}

Berkenaan dengan perbuatan apa saja yang dapat ditetapkan sebagai tindak pidan, beberapa ahli hukum telah mengemukakan pandangannya tentang apa yang disebut dengan tindak pidana. Dari istilah saja, dapat kita temui beberapa istilah yang pengertiannya sama. Istilah itu misalnya tindak pidana, delik, peristiwa pidana, perbuatan yang boleh dihukum, perbuatan pidana, strafbaar feit, dan sebagainya.

Perbuatan pidana merupakan suatu istilah yang mengandung suatu pengertian dasar dalam ilmu hukum, yang dibentuk oleh kesadaran dalam membarikan ciri tertentu pada peristiwa hukum pidana.71 Didalam perundang-undangan dipakai istilah perbuatan pidana, peristiwa pidana, dan tindak pidana, yang sering juga disebut delict. Apa yang dimaksud dengan istilah tindak pidana itu atau dalam bahasa Belanda strafbaar feit sebenarnya merupakan istilah resmi yang terdapat dalam Kitab Undang-Undang Hukum Pidana yang sekarang berlaku di Indonesia. Adapun dalam istilah bahasa asing adalah delict.

Berikut merupakan pendapat para ahli hukum mengenai istilah tindak pidana, antara lain; (a) Moeljatno berpendapat perbuatan pidana adalah perbuatan yang dilarang oleh suatu aturan hukum larangan mana disertai ancaman (sanksi) yang berupa pidana tertentu, bagi barang siapa melanggar larangan tersebut; (b) Pompe merumuskan bahwa suatu tindakan yang menurut suatu rumusan undang-undang telah dinyatakan sebagai tindakan yang dapat dihukum; (c) Vos merumuskan bahwa suatu strafbaar feit itu adalah kelakuan manusia yang diancam pidana oleh peraturan perundang-undangan; (d) Simons merumuskan strafbaar feit adalah suatu tindakan melanggar hukum yang dengan sengaja telah dilakukan oleh seseorang yang dapat dipertanggungjawabkan atas tindakannya, yang dinyatakan sebagai dapat dihukum; (e) J.E. Jonkers merumuskan peristiwa pidana adalah perbuatan pidana yang melawan hukum (wederrechttlijk) yang berhubungan dengan kesengajaan atau kesalahan yang dilakukan oleh orang yang dapat dipertanggungjawabkan; (f) Wirjono Prodjodikoro, bahwa tindak pidana itu adalah suatu perbuatan yang pelakunya dapat dikenakan hukuman pidana; (g) H.J Van Schravendijk merumuskan perbuatan yang boleh dihukum adalah kelakuan orang yang begitu bertentangan dengan keinsyafan hukum sehingga kelakuan itu diancam dengan hukuman, asal dilakukan oleh seseorang yang karena itu dipersalahkan; (h) E. Utrecht menerjemahkan istilah strafbaar feit dengan istilah peristiwa pidana yang sering juga disebut delik, karena peristiwa itu suatu perbuatan handelen atau doein-positif atau sarana melalaikan natalen-negatif, maupun 
akibatnya (keadaan yang timbul karena perbuatan atau melalaikan itu). Peristiwa pidana merupakan suatu peristiwa hukum (rechtfeit), yaitu peristiwa kemasyatakatan yang membawa akibat yang diatur oleh hukum.

Berdasarkan pendapat-pendapat diatas, maka dapat diartikan apa yang dimaksud dengan tindak pidana adalah suatu perbuatan yang dilakukan manusia yang dapat bertanggung jawab yang mana perbuatan tersebut dilarang atau diperintahkan atau dibolehkan oleh undang-undang yang diberi sanksi berupa sanksi pidana. Kata kunci untuk membedakan suatu perbuatan sebagai tindak pidana atau bukan adalah apakah perbuatan tersebut diberi sanksi pidana atau tidak.

\section{Unsur-Unsur tindak Pidana}

\section{Unsur Rumusan Tindak Pidana Dari Sudut Teoritis}

Artinya berdasarkan pendapat para ahli hukum unsur-unsur yang ada dalam tindak pidana adalah melihat bagaimana yang tercermin pada bunyi rumusannya. Menurut Moeljatno, unsur tindak pidana adalah; (1) Perbuatan; (2) Yang dilarang (oleh aturan hukum); (3) Ancaman pidana (bagi yang melanggar larangan).

Menurut R. Tresna tindak pidana trdiri dari unsur-unsur; (1) Perbuatan/rangkaian perbuatan (manusia); (2) Yang bertentangan dengan peraturan perundang-undangan; (3) Diadakan tindakan penghukuman.

Menurut Vos, unsur tindak pidana adalah; (1) Kelakuan manusia; (2) Diancam dengan pidana; (3) Dalam peraturan perundang-undangan.

Menurut J.E Jonkers (penganut paham monism) unsur tindak pidana adalah; (1) Perbuatan (yang); (2) Melawan hukum (yang berhubungan dengan); (3) Kesalahan (yang dilakukan oleh orang yang dapat); (4) Dipertanggungjawabkan.

Menurut H.J Van Schravendijk unsur tindak pidana adalah; (1) Kelakuan (orang yang); (2) Bertentangan dengan keinsyafan hukum; (3) Diancam dengan hukuman; (4) Dilakukan oleh orang (yang dapat); (5) Dipersalahkan/kesalahan.

\section{Unsur Rumusan Tindak Pidana dalam Undang-Undang}

Buku II Kitab Undang-Undang Hukum Pidana (KUHP) memuat rumusan-rumusan perihal tindak pidana tertentu yang masuk dalam kelompok kejahatan, dan buku III memuat pelanggaran. Dari rumusan-rumusan tindak pidana tertentu dalam Kitab Undang-Undang Hukum Pidana (KUHP) itu dapat diketahui adanya 11 (sebelas) unsur tindak pidana, yaitu; (1) Unsur tingkahlaku; (2) Unsur melawan hukum; (3) Unsur kesalahan; (4) Unsur akibat konstitutif; (5) Unsur keadaan 
yang menyertai; (6) Unsur syarat tambahan untuk dapatnya dituntut pidana; (7) Unsur syarat tambahan untuk memperberat pidana; (8) Unsur syarat tambahan untuk dapatnya dipidana; (9) Unsur objek hukum tindak pidana; (10) Unsur kualitas subjek hukum tindak pidana; (11) Unsur syarat tambahan untuk memperingan pidana.

Dari 11 (sebelas) unsur itu, diantaranya dua unsur, yaitu kesalahan dan melawan hukum yang termasuk unsur subjektif, sedangkan selebihnya berupa unsur objektif.

\section{SIMPULAN}

Pada perkara Nomor 105/Pid.B/2017/PN.Son Majelis Hakim memutuskan bahwa terdakwa telah terbukti secara sah dan meyakinkan bersalah telah melakukan tindak pidana "Menyalahgunakan Pengangkutan Dan Niaga Bahan Bakar Minyak Yang Disubsidi Pemerintah. Terdakwa MUNAWAR KHALIL Alias ALE telah terbukti melanggar Pasal 55 UU RI No. 22 Tahun 2001 tentang Minyak dan Gas Bumi. Namun, menurut penulis hakim dan Jaksa Penuntut Umum dalam menerapkan hukum pidana lebih tepat jika memutus terdakwa melanggar Pasal 53 Undang-undang Nomor 22 Tahun 2001 tentang Minyak dan Gas Bumi.

Dalam memutus suatu perkara, Majelis Hakim Pengadilan Negeri Sorong lalai dalam menerapkan hukum dengan tidak mempertimbangkan secara matang dakwaan dari Jaksa Penuntut Umum. Majelis Hakim menjatuhkan vonis kepada terdakwa Pasal 55 Undang-undang Nomor 22 Tahun 2001 bukan Pasal 53 Undang- undang Nomor 22 Tahun 2001, sehingga putusan hakim dapat dikatakan keliru.

\section{DAFTAR PUSTAKA}

Abdulkadir Muhammad, 2006. Etika Profesi Hukum. Bandung :PT Citra Aditya Bakti.

Adami Chazawi, 2002.Pelajaran Hukum Pidan Bagian I. Jakarta:PT Raja Grafindo Persada.

Barda Nanawi Arif, 2008. Masalah Penegakan Hukum dan Kebijakan Hukum Pidana Dalam Penanggulangan Kejahatan, Jakarta: Kencana.

Pipin Syarifin,2000. Hukum Pidana Indoneisa. Bandung: Bustaka Setia

Ronny Hanitijo Soemitro, 2001.Metodologi Penelitian Hukum dan Jurimetri. Jakarta:Ghalia Indonesia.

Siswanto Sunarso,2004. Penegakan Hukum Psikotropika Dalam Kajian Sosiologi Hukum. Jakarta:PT Raja Grafindo Persada. 
Soerjono Soekanto \& Sri Mamudji, 2001.Penelitian Hukum Normatif (Suatu Tinjauan Singkat), Jakarta:Rajawali Pers.

Sudarto, 2006.Kapita Selekta Hukum Pidana.Bandung:PT Alumni.

T. H.Ranidajita, 1994. Eksistensi Pidana dalam Hukum administrasi Negara, FH Undip.

Wirjono Prodjodikkono, 2003.Asas-Asas Hukum Pidana di Indonesia, Bandung :Refika Aditama, 